\title{
THE
}

2006

\section{Transmission loss in manatee habitats}

Jennifer L. Miksis-Olds

University of Rhode Island

James $\mathrm{H}$. Miller

University of Rhode Island, miller@uri.edu

Follow this and additional works at: https://digitalcommons.uri.edu/gsofacpubs

Terms of Use

All rights reserved under copyright.

\section{Citation/Publisher Attribution}

Miksis-Olds, J. L., \& Miller, J. H. (2006). Transmission loss in manatee habitats. Journal of Acoustical Society of America, 120(4), 2320-2327. doi: 10.1121/1.2258832

Available at: https://doi.org/10.1121/1.2258832

This Article is brought to you for free and open access by the Graduate School of Oceanography at DigitalCommons@URI. It has been accepted for inclusion in Graduate School of Oceanography Faculty Publications by an authorized administrator of DigitalCommons@URI. For more information, please contact digitalcommons-group@uri.edu. 


\section{Transmission loss in manatee habitats}

Jennifer L. Miksis-Olds, and James H. Miller

Citation: The Journal of the Acoustical Society of America 120, 2320 (2006); doi: 10.1121/1.2258832

View online: https://doi.org/10.1121/1.2258832

View Table of Contents: http://asa.scitation.org/toc/jas/120/4

Published by the Acoustical Society of America

\section{Articles you may be interested in}

Noise level correlates with manatee use of foraging habitats

The Journal of the Acoustical Society of America 121, 3011 (2007); 10.1121/1.2713555

Manatee (Trichechus manatus) vocalization usage in relation to environmental noise levels

The Journal of the Acoustical Society of America 125, 1806 (2009); 10.1121/1.3068455

The underwater audiogram of the West Indian manatee (Trichechus manatus)

The Journal of the Acoustical Society of America 105, 3575 (1999); 10.1121/1.424681

Determination of West Indian manatee vocalization levels and rate

The Journal of the Acoustical Society of America 115, 422 (2004); 10.1121/1.1635839

Intraspecific and geographic variation of West Indian manatee (Trichechus manatus spp.) vocalizations (L)

The Journal of the Acoustical Society of America 114, 66 (2003); 10.1121/1.1582862

The acoustic environment of the Florida manatee: Correlation with level of habitat use

The Journal of the Acoustical Society of America 115, 2558 (2004); 10.1121/1.4783911 


\title{
Transmission loss in manatee habitats
}

\author{
Jennifer L. Miksis-Olds ${ }^{a)}$ \\ Graduate School of Oceanography, University of Rhode Island, Narragansett, Rhode Island 02882 \\ James H. Miller ${ }^{\text {b) }}$ \\ Department of Ocean Engineering and Graduate School of Oceanography, University of Rhode Island, \\ Narragansett, Rhode Island 02882
}

(Received 22 February 2006; revised 29 June 2006; accepted 6 July 2006)

\begin{abstract}
The Florida manatee is regularly exposed to high volumes of vessel traffic and other human-related noise because of its coastal distribution. Quantifying specific aspects of the manatee's acoustic environment will allow for a better understanding of how these animals respond to both natural and human-induced changes in their environment. Transmission loss measurements were made in 24 sampling sites that were chosen based on the frequency of manatee presence. The Monterey-Miami Parabolic Equation model was used to relate environmental parameters to transmission loss in two extremely shallow water environments: seagrass beds and dredged habitats. Model accuracy was verified by field tests at all modeled sites. Results indicated that high-use grassbeds have higher levels of transmission loss for frequencies above $2 \mathrm{kHz}$ compared to low-use sites of equal food species composition and density. This also happens to be the range of most efficient sound propagation inside the grassbed habitat and includes the dominant frequencies of manatee vocalizations. The acoustic environment may play a more important role in manatee grassbed selection than seagrass coverage or species composition, as linear regression analysis showed no significant correlation between usage and either total grass coverage, individual species coverage, or aerial pattern. (c) 2006 Acoustical Society of America. [DOI: 10.1121/1.2258832]
\end{abstract}

PACS number(s): 43.80.Ev, 43.80.Nd [WWA]

Pages: $2320-2327$

\section{INTRODUCTION}

In order to better understand how sound may affect manatees in critical habitats, it is necessary to quantify the acoustic propagation loss characteristics of these extremely shallow-water regions. Transmission loss is particularly important to characterize because the sonar equation incorporates this term when relating received levels to both source levels and issues of detection (Urick, 1983). Geographically speaking, shallow water refers to the inland waters of bays and harbors and to coastal waters less than $200 \mathrm{~m}$ deep (Etter, 1996). The depth of manatee habitats covers only the shallowest $5 \%$ of that range.

Compared to sound propagation in deep water, the propagation of sound in shallow water is complicated. The difficulty in characterizing transmission loss in shallow water regions is due to the complex variability of environmental conditions in space and time, as well as the interactions between the upper and lower boundary layers. The range of detection in shallow waters is severely limited by high attenuation resulting from repeated interactions with the bottom and by limited water depths, which do not affect the long-range propagation paths in deep water (Etter, 1996). The challenges associated with characterizing sound propagation and signal detection in shallow water has resulted in numerous theories and mathematical models aimed at inte-

\footnotetext{
${ }^{a)}$ Current affiliation: School for Marine and Science Technology, University of Massachusetts Dartmouth, 706 S. Rodney French Blvd., New Bedford, MA 02744; electronic mail: jmiksis@umassd.edu

${ }^{b)}$ Electronic mail: miller@oce.uri.edu
}

grating acoustic and boundary conditions with transmission loss (Officer, 1958; Brekhovskikh, 1960; Urick, 1983; Frisk, 1994; Etter, 1996).

Unfortunately simple transmission loss models are not accurate for the complex intra-coastal environments that manatees inhabit. Nowacek et al. (2001) found that frequencies of sound produced by boats are attenuated in manatee habitats to a greater degree than would be predicted by simple transmission loss models. More detailed mathematical models are needed. Recently, modified parabolic equation (PE) models have been used successfully in shallow-water environments (Jensen, 1984; Etter, 1996; Smith, 2001). These models are based on a solution of the parabolic versus elliptic-reduced wave equation, which is used with ray theory and normal mode models. The PE models are most appropriate for use in range-dependent environments and can be used over a broad frequency band (Jensen, 1982; Collins and Chin-Bing, 1990; Orchard et al., 1992; Etter, 1996; Smith, 2001).

The Monterey-Miami Parabolic Equation (MMPE) model was the specific PE model used in this study. The MMPE model produces solutions which are just as accurate as a benchmark quality model given a real ocean environment with inherent uncertainties. The efficiency of this model in producing both continuous wave and broadband pulse predictions makes it an attractive and powerful tool for ocean acoustic propagation modeling (Smith, 2001). The MMPE model is a numerical, far-field approximation of the horizontal acoustic propagation from a source in which the pressure field is represented by an outgoing Hankel function slowly modulated by an envelope function (Smith and Tap- 
pert, 1993). The current version of MMPE is a twodimensional PE model that employs a split-step Fourier algorithm and assumes the surface is a perfect reflector due to a pressure release boundary. Input parameters needed to run the model are: sound speed profile, range-dependent bathymetry contour, sediment properties (sound speed, sound speed gradient, density, compressional attenuation, shear speed, and shear attenuation), source depth, and source type. The MMPE model also allows for an additional bottom layer to be present on top of the deep basement layer to allow for the effect of sediment or grass layers (Smith, 2001).

Understanding how sound is propagated in different manatee habitats is critical in order to more clearly understand the impact of human activities on manatees and the manatee communication system. For example, watercraft collisions have become the leading cause of adult mortality (Ackerman et al., 1995; Reynolds, 1995). The question that naturally arises from this is whether or not manatees are hearing the noise produced from approaching boats in enough time to swim out of harm's way. The root of this question is the detection of sound signals. Quantifying sound propagation in different habitats provides one element of information necessary for determining received levels and ultimately the probability of manatees detecting approaching sound sources. Establishing whether manatees are discriminating between habitats that provide either more or less efficient sound propagation is a second logical element that needs to be addressed. The purpose of the study was to investigate manatee habitat use in relation to transmission loss.

\section{METHODS}

\section{A. Site selection and habitat use}

Sound propagation loss was investigated in two manatee habitats: seagrass beds and dredged habitats. These habitat types were chosen because of their biological importance to manatees. Animals typically feed in grassbeds and rest or socialize in dredged habitats (Koelsch, 1997). Habitats used by manatees in the Sarasota Bay, FL area were identified from aerial survey data available from Mote Marine Laboratory for the years 2000-2003 (Gannon et al. (in press); Lefebvre et al., 1995). A total of 24 sites were selected for acoustic and environmental sampling: 13 grassbeds and 11 dredged habitats. Grassbed sites were defined by the presence of seagrass within the site, and dredged habitats were areas that had been dredged for human use and were characterized by the presence of a fine sediment layer. There were two selection criteria for site selection. First, manatees had to be observed in a site more than once over the 4-year survey period from 2000-2003. Second, the site had to be accessible by the $5.2 \mathrm{~m}(17 \mathrm{ft})$ research vessel.

The percentage of surveys in which animals were sighted in the selected grassbeds ranged from $5.3 \%$ to $78.9 \%$. The percentage of surveys in which animals were observed in the dredged habitats ranged from $5.3 \%$ to $39.5 \%$ (Table I). The 13 grassbed sites included the five most heavily used grassbeds identified from the aerial surveys, one of which was in a manatee sanctuary (Pansy Bayou Grassbed or Pansy GB). The grassbed sites also included the five least
TABLE I. Selected grassbed and dredged habitat sites with associated usage patterns.

\begin{tabular}{lccccc}
\hline \hline Site & Grassbed & $\begin{array}{c}\text { Usage } \\
(\%)\end{array}$ & Site & Dredged habitat & $\begin{array}{c}\text { Usage } \\
(\%)\end{array}$ \\
\hline A & City Island Grassflats & 78.9 & $\mathbf{C}$ & Pansy DC & 39.5 \\
& (CIGF) & & & & \\
$\mathbf{B}$ & Pansy Bayou GB & 73.7 & $\mathbf{W}$ & Buttonwood Canal & 23.7 \\
$\mathbf{V}$ & Buttonwood Harbor S & 44.7 & $\mathbf{U}$ & Bowlees Creek & 15.8 \\
$\mathbf{H}$ & S. Sarasota Bay & 44.7 & $\mathbf{K}$ & Cluster & 13.2 \\
$\mathbf{I}$ & W. Roberts Bay & 44.7 & $\mathbf{M}$ & E. Roberts Bay & 13.2 \\
$\mathbf{T}$ & Bowlees GB & 18.4 & $\mathbf{L}$ & Phillipi Creek & 13.2 \\
$\mathbf{N}$ & SE Sarasota Bay & 18.4 & $\mathbf{J}$ & Cocoanut Bayou & 10.5 \\
$\mathbf{S}$ & Airport GB & 15.8 & $\mathbf{R}$ & Whitacker Bayou & 5.3 \\
$\mathbf{D}$ & CIGF East & 10.5 & $\mathbf{Q}$ & Hyatt Basin & 5.3 \\
$\mathbf{F}$ & SW Bird Key & 10.5 & $\mathbf{E}$ & S. Lido Canal & 5.3 \\
$\mathbf{X}$ & New Pass GB & 7.9 & $\mathbf{P}$ & Harbor Acres & 5.3 \\
$\mathbf{G}$ & Down South Lido & 7.9 & & & \\
$\mathbf{O}$ & E. Sarasota Bay & 7.9 & & & \\
\hline \hline
\end{tabular}

used grassbeds in Sarasota Bay meeting the selection criteria. The 11 dredged habitat sites included the three most heavily used dredged basins/canals, one of which was in a manatee sanctuary (Pansy Dredged Basin or Pansy DB). The dredged sites also included the four least used dredged habitats in Sarasota Bay meeting the selection criteria.

\section{B. Transmission loss}

The MMPE model was used to model the sound propagation loss at sites within the Sarasota Bay area (Smith, 2001). Transmission loss in a seven-octave frequency band was modeled from $250 \mathrm{~Hz}$ to $20 \mathrm{kHz}$ over a range of $100 \mathrm{~m}$. Transmission loss was quantified for eight frequencies: 250, $500 \mathrm{~Hz}, 1,2,4,8,16$, and $20 \mathrm{kHz}$. The $20 \mathrm{kHz}$ frequency was chosen as the maximum because this was the maximum frequency output of the broadcasting system used during the field test validations. Initial environmental parameters were collected during the summer of 2003 for application in the MMPE model. A SBE 25 SEALOGGER CTD was used to monitor salinity, temperature, and sound speed profiles in each site over the course of the season. Each environmental input parameter was averaged for a 6-month time period, and the average sound speed value was used in the MMPE model for each site. The largest difference between the average 6-month sound speed profile and any individual sample within each site was less than $1.5 \%$; therefore the seasonal variation in the sound speed profiles had a negligible effect on model predictions. Bathymetry data were obtained by doing transects across each site. A bathymetry reading was recorded approximately every $10 \mathrm{~m}$. Sediment properties were obtained from the Sarasota Bay National Estuary Program (Culter and Leverone, 1993). Distribution of sediment grain sizes in each site was identified from Culter and Leverone (1993). The proportion of grain sizes in each site was then used to estimate sediment sound speed, sound speed gradient, density, and compressional attenuation loss from Hamilton (1980).

The modeled transmission loss range in all sites was approximated from the distance between the closest boat 
channel and the farthest possible manatee position within a given site. A point source at a depth of $0.75 \mathrm{~m}$ was used in all models in order to most closely simulate the depth of an outboard motor. A $50 \mathrm{~m}$ sediment layer was used in all dredged habitat model runs. The $50 \mathrm{~m}$ sediment layer width was chosen because it was the minimum layer width that produced no interaction with the rock layer deep below the sediment layer. In seagrass beds, the transmission loss was modeled with a $0.3 \mathrm{~m}$ grass layer on top of a $50 \mathrm{~m}$ sediment layer. All grassbed sites were modeled with the same grass layer acoustic properties. These properties were approximated for turtle grass (Thalassia testundinum), the dominant seagrass species in the 13 selected grassbed sites. Grass layer velocity $(1450 \mathrm{~m} / \mathrm{s})$, density $\left(0.90 \mathrm{~g} / \mathrm{cm}^{3}\right)$, and attenuation loss $(0.17 \mathrm{~dB} / \mathrm{km} / \mathrm{Hz})$ were derived from grass blade density and physiological and biomechanical properties of turtle grass in Sarasota Bay, FL (Tomasko et al., 1996; Sabol (private communication)). Density values were taken directly from measured values, whereas velocity and attenuation loss values were estimated based on the cross-sectional ratio of gas-filled lacunae and plant tissue. It was assumed from previous work on the acoustic reflectivity of aquatic vegetation that plant tissue had the acoustic properties of seawater, while the lacunae had acoustic properties of air (Sabol et al., 1997; Kopp, 1998; Sabol et al., 2002). The $0.90 \mathrm{~g} / \mathrm{cm}^{3}$ density value reflects the density of the grass blades themselves. In situ biomass density is variable and was not measured directly; consequently in situ biomass was not used as a model input. However, in situ biomass can be approximated if the area grass blade density is known. For example, an approximate $3 \mathrm{~kg} / \mathrm{m}^{2}$ grass density roughly corresponds to $1.1 \%$ of the volume of a $1 \mathrm{~m}^{2}$ by $0.3 \mathrm{~m}$ deep volume of water. Using a seawater density of $1.0247 \mathrm{~g} / \mathrm{cm}^{3}$, the layer density would be approximately $1.0233 \mathrm{~g} / \mathrm{cm}^{3} \quad(0.011$ $\left.\times 0.9 \mathrm{~g} / \mathrm{cm}^{3}+0.989 \times 1.0247 \mathrm{~g} / \mathrm{cm}^{3}\right)$.

The MMPE model outputs transmission loss in three forms: TL at a single frequency versus range and depth, TL at a single range versus frequency and depth, and TL at a single depth versus frequency and range. All results in this study were based on the output of TL at a single frequency versus range and depth. In order to quantitatively compare $\mathrm{TL}$ at a specified range and frequency between sites, TL was averaged over the depth of the water column at ranges of interest. The concept of averaging over the depth of the water column also has a biological basis, as the direct channels of manatee sound reception are not completely clear. Manatees have been shown to sense sound pressure levels in the region of the head, but it has also been suggested that the short hairs uniformly spaced over their body may detect particle displacement (Gerstein et al., 1999). All dB units were converted to intensity before averaging and re-converted back to $\mathrm{dB}$ units for final calculations.

A difference technique was used to validate the MMPE model outputs. Difference techniques measure the distance between the model prediction and field measurements in terms of dB difference at a given range (Etter, 1996). Model accuracy was verified at all sites by recording a broadband signal transmitted from an anchored boat a known distance away. The broadcast signal was a $1 \mathrm{~s}$ frequency sweep span-

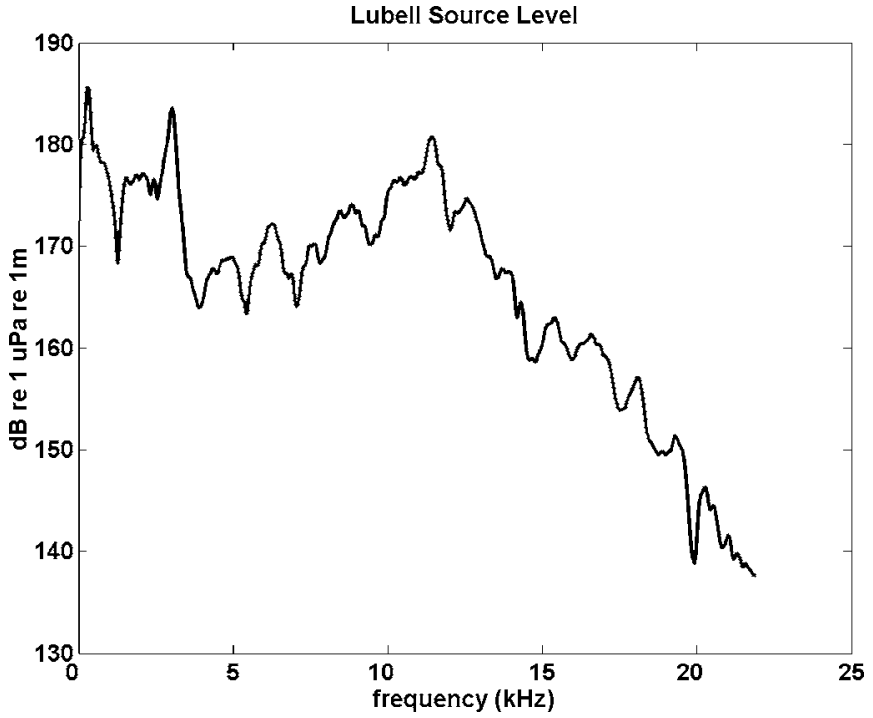

FIG. 1. Source level of $1 \mathrm{~s}$ frequency sweep transmitted from the Lubell LL916 transducer. Raw data were processed to provide the source level in $\mathrm{dB}$ re $1 \mu \mathrm{Pa}$ rms at $1 \mathrm{~m}$.

ning $20 \mathrm{~Hz}-22 \mathrm{kHz}$. In 2003, the frequency sweep was introduced by a $\mathrm{J}-9$ underwater transducer, which is capable of producing sounds in the range of $40 \mathrm{~Hz}-20 \mathrm{kHz}$ with a source level near $160 \mathrm{~dB}$ re $1 \mu \mathrm{Pa}$ at $1 \mathrm{~m} .{ }^{1}$ In 2004, a Lubell LL916 underwater loudspeaker system was used as a source. This system had a $200 \mathrm{~Hz}-20 \mathrm{kHz}$ frequency range with an output source level of $180 \mathrm{~dB}$ re $1 \mu \mathrm{Pa}$ at $1 \mathrm{~m} .{ }^{1}$ Neither transducer had a flat frequency response in the $20 \mathrm{~Hz}-$ $22 \mathrm{kHz}$ range, so a source level measurement for the frequency sweeps was recorded at a $1 \mathrm{~m}$ distance in each site to obtain a frequency-dependent source level for transmission loss calculations (Fig. 1). Figure 1 was processed to provide the source level in $\mathrm{dB}$ re $1 \mu \mathrm{Pa}$ rms at $1 \mathrm{~m}$.

Transmission loss was calculated by subtracting the received levels of signals recorded at a distance of 5, 10, 25, and $50 \mathrm{~m}$ from the $1 \mathrm{~m}$ source level at each of the eight modeled frequencies in all sites. Additional measurements at $100 \mathrm{~m}$ were made in two dredged habitat sites. All settings of the broadcasting system remained constant throughout the study. The dynamic range of the recording system was varied to prevent overloading the system. The recording hydrophone was a HTI-99-HF hydrophone with built-in preamplifier and had a $2 \mathrm{~Hz}-125 \mathrm{kHz}$ frequency range and $-178 \mathrm{~dB}$ re $1 \mathrm{~V} / \mu \mathrm{Pa}$ sensitivity. The recording system was a National Instruments PCMCIA DAQ Card-6062E used in conjunction with a Dell Inspiron 8100. This system had a frequency response of $5 \mathrm{~Hz}-250 \mathrm{kHz}$ with a selectable input voltage range. All recordings were sampled at a rate of $200 \mathrm{kHz}$.

Model accuracy was evaluated by examining field measurements with respect to model output as a function of range and frequency (Fig. 2). Figure 2 illustrates how the MMPE model outputs for each model run were viewed in relation to the field measurements. Each MMPE model output was examined on two levels: TL at the depth of the hydrophone and TL depth averaged over the water column as a function of distance. In grassbeds the hydrophone depth was $1 \mathrm{~m}$, and the depth of the hydrophone in dredged habi- 

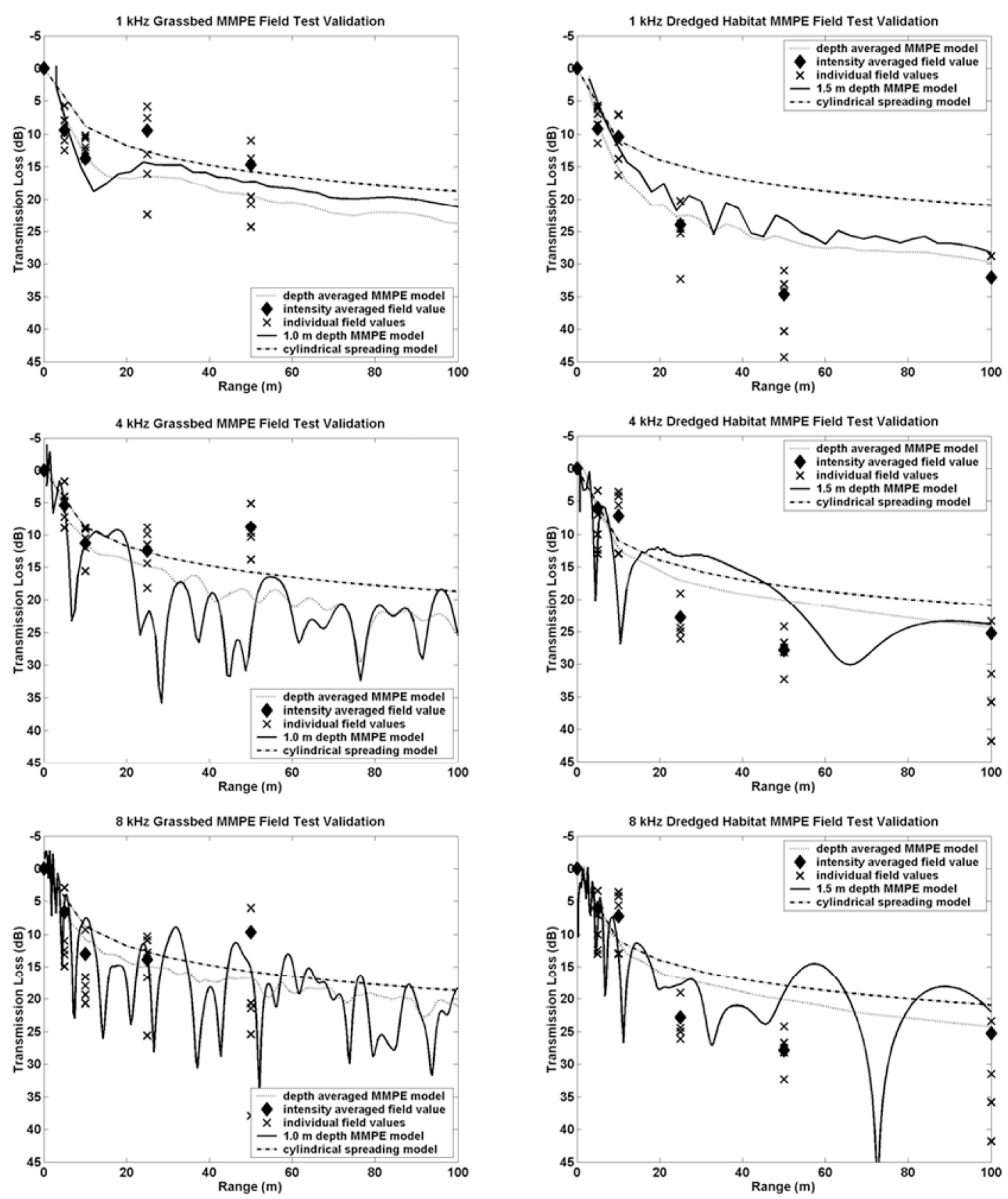

FIG. 2. Model predictions and field measurements for transmission loss at threefrequencies in a single grassbed and dredged habitat. The intensity averaged field value at a specified distance is represented by a diamond. " $\times$ " symbols represent the individual measurements from which the average was calculated. The solid line represents the MMPE model output at the depth of the hydrophone making the field measurements $(1.0 \mathrm{~m}$ in grassbeds and $1.5 \mathrm{~m}$ in dredged habitats). The dotted line is the depth averaged TL estimated in the water column by the MMPE model over the $100 \mathrm{~m}$ range. The cylindrical spreading model is presented by a dash-dot line for comparison to the MMPE model results. Input parameters for the model run in each site are detailed in Table II. Note: transmission loss was so great in grassbeds at $100 \mathrm{~m}$ that no field calculation was possible.

tats was $1.5 \mathrm{~m}$. A cylindrical spreading model (TL $=10 \log (r)+10 \log (h))$ was included for comparison. Deviations between the model and field measurements were calculated at the hydrophone depth [hydrophone depth $=1 \mathrm{~m}$ in grassbeds and $1.5 \mathrm{~m}$ in dredged habitats] (Figs. 2 and 3).

\section{Seagrass habitat density estimates}

Seagrass density was estimated for the area's three most prominent seagrass species: turtle grass (Thalassia testudinum), manatee grass (Syringodium filiforme), and shoal grass (Halodule wrightii). In-water estimates were obtained using standard procedures for shoot density and biomass (Tomasko and Dawes, 1989). A $1 \mathrm{~m}^{2}$ quadrant, which was divided into 25 equal $20 \times 20 \mathrm{~cm}$ squares, was cast six times in each seagrass habitat. The total grass coverage, as well as individual grass species and macroalgae coverage, was evaluated for each quadrant toss. The values were then averaged to determine a final species and total grass coverage percentage for each site.

Seagrass patterns within each site were also estimated from an aerial survey flown on 16 June 2004. Grass patterns were evaluated on a 5-point scale ranging from sparse to 
뜸

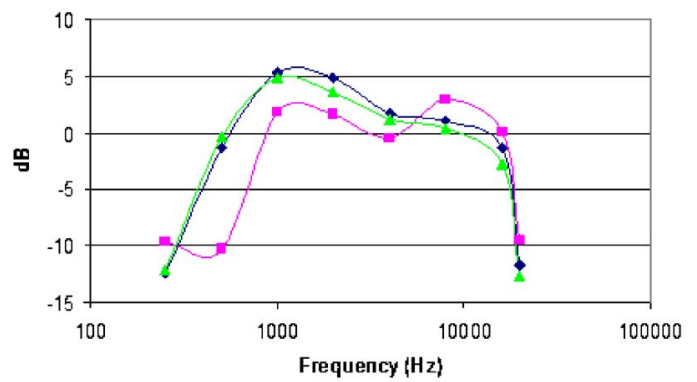

B)

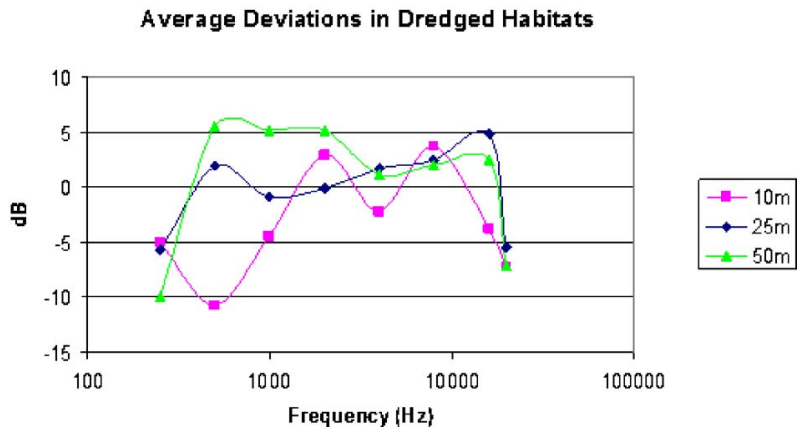

FIG. 3. Average deviations of field measurements from MMPE model predictions at the hydrophone depth for transmission loss in grassbeds (A) and dredged habitats (B). Hydrophone depth in the grassbeds was $1 \mathrm{~m}$. Hydrophone depth in the dredged habitats was $1.5 \mathrm{~m}$. Deviations are shown for measurements at three specified ranges. Negative values indicate the model overestimated the TL, and positive values indicate the model underestimated the TL.

dense grass coverage. The categories were: (1) sparse, (2) sparsely patchy, (3) densely patchy, (4) continuous (moderate cover), and (5) dense. All references to seagrass habitat quality in this work pertain only to the parameters of density and species composition. It was assumed that quality is dependent on the availability of the three most highly consumed seagrass species in Florida and does not take into account other previously used parameters to assess seagrass quality such as shoot age, weight of plant material, time spent chewing, etc. (Bengtson, 1983).

\section{RESULTS}

Initial MMPE model results comparing TL across habitat types supported documented evidence from previous manatee habitat TL experiments which reported higher levels of transmission loss in grassbeds compared to dredged habitats (Nowacek, 2001). Modeled and measured transmission loss was often greater in grassbeds than in adjacent dredged basins or canals at close ranges and always greater at the range of $100 \mathrm{~m}$. The transmission loss in grassbeds at $100 \mathrm{~m}$ was so great that signals could not be detected for TL calculations (Fig. 2). This pattern was consistent for all frequencies modeled. Model results also indicated that the highest TL occurred at frequencies below $2 \mathrm{kHz}$, whereas the most efficient frequencies of sound propagation were $2-20 \mathrm{kHz}$ in both grassbeds and dredged habitats.

When deviations between the field measurements and model calculations at the hydrophone depth were averaged over all the sites as a function of habitat type, range, and frequency, results indicated that the MMPE model was most accurate for frequencies from 1 to $16 \mathrm{kHz}$ (Fig. 3). In this frequency range, average deviations were predominantly within $\pm 5 \mathrm{~dB}$. Deviations were averaged without taking the absolute values of the differences to identify biases. Negative deviation values indicated the model overestimated the TL, and positive values indicated the model underestimated the TL. An example of model parameters with their estimated errors for both a grassbed and dredged habitat site are presented in Table II. The origin of deviations between the model and field measurements is most likely due to errors in the environmental input parameters to the computational model.

TABLE II. Example of MMPE model input parameters with their estimated errors for both a grassbed and dredged habitat site. Depth errors are based on a $0.1 \mathrm{~m}$ oscillation of the research vessel due to waves, which adds a greater error component to shallow water depths. Note: depth is the only range-dependent variable in these very shallow, well-mixed environments.

\begin{tabular}{|c|c|c|c|c|c|c|}
\hline & \multicolumn{3}{|c|}{ GB site } & \multicolumn{3}{|c|}{ Dredged site } \\
\hline & Value & Max error & $\%$ error & Value & Max error & $\%$ Error \\
\hline \multicolumn{7}{|l|}{ Depth at range } \\
\hline $1 \mathrm{~m}$ & 2.0 & 0.1 & 5 & 1.9 & 0.1 & 5 \\
\hline $5 \mathrm{~m}$ & 2.3 & 0.1 & 4 & 1.8 & 0.1 & 6 \\
\hline $10 \mathrm{~m}$ & 1.7 & 0.1 & 6 & 1.8 & 0.1 & 6 \\
\hline $25 \mathrm{~m}$ & 1.7 & 0.1 & 6 & 2.0 & 0.1 & 5 \\
\hline $50 \mathrm{~m}$ & 1.7 & 0.1 & 6 & 2.6 & 0.1 & 4 \\
\hline $100 \mathrm{~m}$ & 1.1 & 0.1 & 9 & 2.6 & 0.1 & 4 \\
\hline Sound speed $(\mathrm{m} / \mathrm{s})$ & 1549.0 & 0.01 & $<1$ & 1544.0 & 0.01 & $<1$ \\
\hline Grass layer velocity (m/s) & 1450.0 & 50 & 3 & & & \\
\hline Grass layer density $\left(\mathrm{g} / \mathrm{cm}^{3}\right)$ & 0.90 & 0.05 & 6 & & & \\
\hline Grass layer attenuation $(\mathrm{dB} / \mathrm{km} / \mathrm{Hz})$ & 0.04 & 0.005 & 12.5 & & & \\
\hline Sediment velocity $(\mathrm{m} / \mathrm{s})$ & 1700.0 & 50 & 3 & 1590 & 50 & 3 \\
\hline Sediment density $\left(\mathrm{g} / \mathrm{cm}^{3}\right)$ & 1.8 & 0.05 & 6 & 1.59 & 0.05 & 6 \\
\hline Sediment attenuation $(\mathrm{dB} / \mathrm{km} / \mathrm{Hz})$ & 0.06 & 0.005 & 8 & 0.1 & 0.005 & 5 \\
\hline
\end{tabular}


TABLE III. Regression analysis $p$ values for transmission loss and usage comparisons at specified distances and frequencies. Shaded values show significant relationships at the $95 \%$ significance level.

\begin{tabular}{llllllr}
\hline \hline Frequency & $10 \mathrm{~m}$ & $20 \mathrm{~m}$ & $25 \mathrm{~m}$ & $50 \mathrm{~m}$ & $100 \mathrm{~m}$ & $200 \mathrm{~m}$ \\
\hline Grassbeds & & & & & & \\
$250 \mathrm{~Hz}$ & $\mathbf{0 . 0 1 9}$ & 0.32 & 0.70 & 0.42 & 0.76 & 0.63 \\
$500 \mathrm{~Hz}$ & 0.57 & 0.41 & 0.79 & 0.33 & 0.57 & 0.78 \\
$1 \mathrm{kHz}$ & 0.14 & 0.13 & 0.23 & $\mathbf{0 . 0 4}$ & 0.08 & $\mathbf{0 . 0 4}$ \\
$2 \mathrm{kHz}$ & 0.096 & $\mathbf{0 . 0 3 5}$ & $\mathbf{0 . 0 4}$ & 0.09 & $\mathbf{0 . 0 0 4}$ & $\mathbf{0 . 0 0 1}$ \\
$4 \mathrm{kHz}$ & $\mathbf{0 . 0 3 0}$ & $\mathbf{0 . 0 3 2}$ & $\mathbf{0 . 0 4}$ & $\mathbf{0 . 0 1}$ & $\mathbf{0 . 0 4 5}$ & $<\mathbf{0 . 0 0 1}$ \\
$8 \mathrm{kHz}$ & $\mathbf{0 . 0 3 7}$ & $\mathbf{0 . 0 3 7}$ & $\mathbf{0 . 0 3}$ & $\mathbf{0 . 0 2}$ & $\mathbf{0 . 0 3 7}$ & $\mathbf{0 . 0 0 6}$ \\
$16 \mathrm{kHz}$ & $\mathbf{0 . 0 2 9}$ & $\mathbf{0 . 0 2 5}$ & $\mathbf{0 . 0 3}$ & $\mathbf{0 . 0 2}$ & $\mathbf{0 . 0 1 6}$ & $\mathbf{0 . 0 0 1}$ \\
$20 \mathrm{kHz}$ & $\mathbf{0 . 0 3 4}$ & $\mathbf{0 . 0 3 3}$ & $\mathbf{0 . 0 3}$ & $\mathbf{0 . 0 2}$ & $\mathbf{0 . 0 1 5}$ & $\mathbf{0 . 0 0 2}$ \\
& & & & & & \\
Dredged habitats & & & & & \\
$250 \mathrm{~Hz}$ & 0.35 & 0.37 & 0.10 & 0.87 & 0.17 & 0.30 \\
$500 \mathrm{~Hz}$ & 0.58 & 0.58 & 0.74 & 0.90 & 0.66 & 0.54 \\
$1 \mathrm{kHz}$ & 0.77 & 0.95 & 0.80 & 0.83 & 0.97 & 0.67 \\
$2 \mathrm{kHz}$ & 0.32 & 0.12 & 0.14 & 0.13 & 0.21 & 0.27 \\
$4 \mathrm{kHz}$ & 0.48 & 0.36 & 0.39 & 0.41 & 0.48 & 0.61 \\
$8 \mathrm{kHz}$ & 0.56 & 0.58 & 0.51 & 0.65 & 0.72 & 0.85 \\
$16 \mathrm{kHz}$ & 0.41 & 0.33 & 0.35 & 0.41 & 0.56 & 0.68 \\
$20 \mathrm{kHz}$ & 0.49 & 0.40 & 0.42 & 0.50 & 0.68 & 0.76 \\
\hline \hline
\end{tabular}

\section{A)}
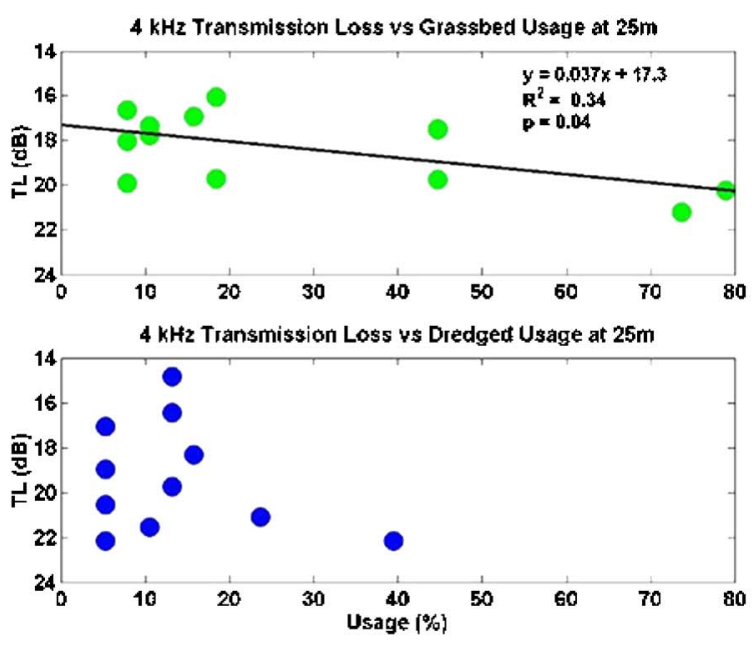

B)
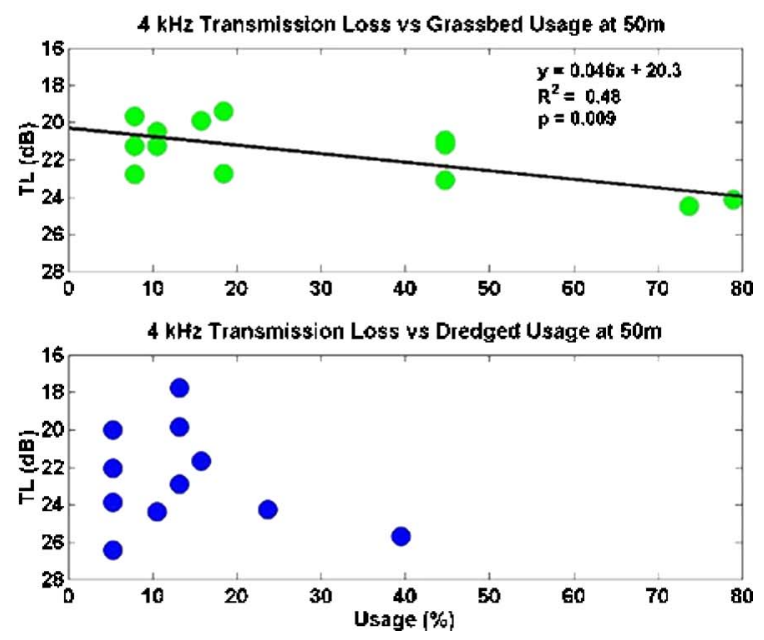

FIG. 4. $4 \mathrm{kHz}$ transmission loss at $25 \mathrm{~m} \mathrm{(A)}$ and $50 \mathrm{~m} \mathrm{(B)}$ as a function of manatee site usage in grassbeds and dredged habitats. Solid regression lines indicate significant relationships in grassbeds.
Depth-averaged TL was calculated from the MMPE model outputs at distances of 10,20,25, 50,100, and $200 \mathrm{~m}$ for each of the eight specified frequencies within each grassbed and dredged habitat site. Transmission loss in shallow water can be a complicated function of frequency due to the interference of the acoustic normal modes with varying phase velocities. For frequencies, separated by an octave, the transmission loss can be well modeled as statistically independent for waveguide depths greater than a wavelength (Bongiovanni et al., 1996). Regression analyses were performed within each habitat type and at each frequency and distance in order to determine if TL was significantly correlated with manatee usage. Usage was defined as the percentage of time manatees were present at a site during aerial surveys from 2000 to 2003 . Results showed a significant correlation between usage and TL in grassbeds at all investigated distances for frequencies from 4 to $20 \mathrm{kHz}$ (Fig. 4 and Table III). Sites that were used more heavily by manatees tended to have higher levels of transmission loss. Significance was observed at some distances, but not all, for frequencies of $1-2 \mathrm{kHz}$. For all significant regressions, $R$ squared values ranged from 0.32 to 0.71 . There was no significant correlation between usage and TL in grassbeds at frequencies below $1 \mathrm{kHz}$ or in dredged habitats at any frequency or distance.

Total seagrass coverage and individual seagrass species coverage varied widely among the 13 seagrass habitats sampled (Table IV). One hundred percent coverage was seen in four sites ranging in usage from $7.9 \%$ to $44.7 \%$. The two most heavily used grassbed sites (A and B) had a total coverage of $91.3 \%$ and $75 \%$, respectively. Linear regression analysis showed no significant correlation between usage and either total grass coverage, individual species coverage, or aerial pattern. This indicates that usage is not a function of seagrass habitat quality in relation to density parameters, but does not necessarily reflect patterns of usage in relation to other unmeasured parameters of seagrass quality (shoot age, plant weight, etc).

\section{DISCUSSION}

Both model results and transmission loss field experiments showed that TL was greater in grassbeds than in adjacent dredged basins. In addition, the most TL occurred for frequencies below $2 \mathrm{kHz}$, whereas the least TL was seen for frequencies from 2 to $20 \mathrm{kHz}$. From a manatee's point of view this would mean that the sounds traveling through the environment least efficiently in both habitats are the lower frequency sounds, which overlap with dominant boat noise frequencies (Richardson et al., 1995; Gerstein, 2002). Conversely, those frequencies that travel through the environment best are those that overlap the peak and fundamental frequencies (peak: 1-12 kHz; fundamental: $1-9 \mathrm{kHz}$ ) of manatee vocalizations (Nowacek et al., 2003). A relatively quiet frequency band has been documented between 1 and $4 \mathrm{kHz}$ in many terrestrial and ocean environments, and this may be one reason why bird and mammal vocalizations fall in these frequencies (Bradbury and Vehrencamp, 1998). It appears that the manatee communication system has adapted 
TABLE IV. Grassbed quality estimates in relation to \% usage. Total coverage of Thalassia testudinum, Syringodium filiforme, Halodule wrightii, and macroalgae values are in $\%$ of total quadrant covered by species. Aerial pattern values are based on a 1-5 point scale. The categories were: (1) sparse, (2) sparsely patchy, (3) densely patchy, (4) continuous (moderate cover), and (5) dense.

\begin{tabular}{|c|c|c|c|c|c|c|c|}
\hline Site & $\begin{array}{c}\% \\
\text { usage }\end{array}$ & $\begin{array}{c}\text { Total } \\
\text { coverage }\end{array}$ & Thalassia & Halodule & Syringodium & Macroalgae & $\begin{array}{l}\text { Aerial } \\
\text { pattern }\end{array}$ \\
\hline $\mathbf{A}$ & 78.9 & 91.3 & 75.3 & 29.3 & 8 & 45.3 & 5 \\
\hline B & 73.7 & 75 & 46.6 & 92.2 & 0 & 4.7 & 4.5 \\
\hline D & 10.5 & 100 & 52.3 & 34 & 0 & 29.3 & 4.5 \\
\hline $\mathbf{F}$ & 10.5 & 100 & 96.7 & 38 & 33.3 & 2 & 3.5 \\
\hline G & 7.9 & 100 & 98.7 & 16.7 & 0 & 76 & 5 \\
\hline $\mathbf{H}$ & 44.7 & 100 & 83.3 & 16.7 & 33.3 & 9.3 & 4 \\
\hline I & 44.7 & 84 & 50 & 17.3 & 0 & 41.3 & 3 \\
\hline $\mathbf{N}$ & 18.4 & 69.3 & 47.3 & 46 & 16.7 & 12.7 & 1 \\
\hline $\mathbf{O}$ & 5.3 & 98 & 53.3 & 28.7 & 32.7 & 27.3 & 3.5 \\
\hline $\mathbf{S}$ & 15.8 & 98 & 96 & 28 & 2.7 & 0.7 & 4 \\
\hline $\mathbf{T}$ & 18.4 & 83.3 & 78 & 33.3 & 0 & 47.3 & 4 \\
\hline $\mathbf{V}$ & 44.7 & 96 & 86 & 34 & 0 & 50.7 & 5 \\
\hline $\mathbf{X}$ & 7.9 & 85.7 & 68.6 & 30.3 & 0 & 24.6 & 3 \\
\hline
\end{tabular}

to capitalize on the acoustics of the shallow water habitats they inhabit over evolutionary time. The presence of lower frequency boat noise in manatee habitats is a relatively new pressure on an evolutionary time scale, and its effects are yet to be fully understood.

Significant correlations of transmission loss and usage were found in grassbed habitats but not in dredged habitats. The exact cause of this observation is not known but could be related to how animals are using each habitat. Manatees typically feed in grassbeds and engage in play or rest while in dredged habitats (Koelsch, 2001). It is possible that manatees are selecting grassbeds that attenuate high levels of noise, allowing them to tolerate higher noise levels while meeting nutritional requirements. Grassbeds in Sarasota Bay, FL tended to be louder than dredged habitats due to the loud broadband noise produced by snapping shrimp (Alpheus and Synalpheus $s p$ ), which becomes stronger with decreasing depth (Richardson et al., 1995; Camp et al., 1998; MiksisOlds, 2006). Manatees may be exposed to lower noise levels when resting or playing in dredged habitats and therefore become less selective in the acoustic properties of the habitat.

One question that naturally arises from the observed relationship is what factor is more dominant in driving the manatee grassbed usage, sound propagation or habitat quality? Dense grassbeds attenuate sound more than sparse grassbeds which may create a quiet area near a high noise traffic zone, yet a sparse grassbed may be located near a less busy boating area but propagate more noise. Dense grassbeds may also complicate the noise and sound propagation by the diversity of fauna living within the habitat (i.e., snapping shrimp, toadfish). Analysis of the seagrass coverage and species composition indicated no correlation between quality, as defined previously, and grassbed usage. This suggests that propagation characteristics associated with transmission loss play a more dominant role in habitat selection than the parameters of seagrass quality investigated in this study.

Making field measurements and using models to determine the transmission loss of a signal in manatee habitats are only two of many elements that must be quantified in order to ultimately answer questions pertaining to habitat selection and signal detection by an animal. Another major factor is noise. The actual range of effective signal transmission in the noisy, shallow-water areas manatees inhabit is dependent on the area noise levels, acoustic propagation loss characteristics, and frequency and amplitude of the signals being produced. Environmental parameters such as water depth, salinity, temperature, bottom type, and wind speed will also affect sound absorption and attenuation. Consequently, sound transmission is different for varying wavelengths in different manatee habitats, and different habitat types may make it easier or more difficult for manatees to detect either conspecific vocalizations or approaching vessels. Compared to the laborious technique of measuring transmission loss in the field, the MMPE model provides a relatively simple and accurate method for quantitatively assessing the transmission loss component involved in issues of signal detection and the impact of noise sources on manatees and other marine mammals living in shallow water environments, given accurate environmental parameters. A firm grasp on environmental noise levels, in addition to transmission loss characteristics, in specific habitats will build upon the work done here and is needed in order to more fully understand questions pertaining to manatee habitat selection and signal detection in these shallow habitats.

\section{ACKNOWLEDGMENTS}

The authors would like to acknowledge the following: Kevin Smith (Naval Postgraduate School) and Gopu Potty (URI Ocean Engineering) provided invaluable information regarding the MMPE modeling. The Manatee Research Program at Mote Marine Laboratory contributed aerial survey information and field interns. The authors would also like to acknowledge Bruce Sabol (Department of the Army, Engineer and Research Development Center) and Brad Robins (Mote Marine Laboratory) for their contribution to the estimates of seagrass acoustic properties and density measure- 
ments. Special thanks are also extended to Peter Tyack (WHOI), John Reynolds (Mote Marine Laboratory), David Farmer (URI), Cheryl Wilga (URI), Bruce Sabol and two anonymous reviewers for comments on previous versions of this manuscript. This research was supported by a P.E.O. Scholar Award and National Defense Science and Engineering Fellowship awarded to Jennifer Miksis.

${ }^{1}$ Source level estimates at the lower end of the frequency band are not expected to be applicable, as the shallow water depths do not allow for free-field source level measurements.

Ackerman, B. B., Wright, S. D., Bonde, R. K., Odell, D. K., and Banowetz, D. J. (1995). "Trends and patterns in mortality of manatees in Florida". in Population Biology of the Florida Manatee (Trichechus manatus latirostris), National Biological Service, Information and Technical Report No. 1, pp. 1974-1992.

Bengtson (1983). "Estimating food consumption of free-ranging manatees in Florida," Journal of Wildlife Management 47: 1186-1192.

Bongiovanni, K., Badiey, M., and Seigmann, W. L. (1996). "Interference patterns of frequency dependent transmission loss for shallow-water propagation,” J. Acoust. Soc. Am. 99, 2523-2529.

Bradbury, J. W., and Vehrencamp, S. L. (1998). Principles of Animal Communication (Sinauer Associates, Sunderland, MA).

Brekhovskikh, L. M. (1960). Waves in a Layered Media (Academic, New York).

Camp, D. K., Lyons, W. G., and Perkins, T. H. (1998). Checklists of Selected Marine Invertebrates of Florida, FMRI Technical Report No. TR-3, Florida Department of Environmental Protections.

Collins, M. D., and Chin-Bing, S. A. (1990). "A three-dimensional parabolic equation model that includes the effects of rough boundaries," J. Acoust. Soc. Am. 87, 1104-1109.

Culter, J. K., and Leverone, J. R. (1993). "Bay bottom habitat assessment," Mote Technical Report No. 303, Mote Marine Laboratory, Sarasota, FL.

Etter, P. C. (1996). Underwater Acoustic Modeling (E \& FN SPON, London).

Frisk, G. V. (1994). Ocean and Seabed Acoustics (PTR Prentice-Hall, Englewood Cliffs, NJ).

Gannon, J. G., Scolardi, K. M., Reynolds, J. E., III, (in press). "Habitat selection by manatees in Sarasota Bay, Florida," Marine Mammal Science.

Gerstein, E. R. (2002). "Manatees, bioacoustics and boats," Am. Sci. 90, $154-163$.

Hamilton, E. L. (1980). "Geoacoustic modeling of the sea floor," J. Acoust. Soc. Am. 68, 1313-1340.

Jensen, F. B. (1982). "Numerical models of sound propagation in real oceans," Proceedings of the MTS/IEEE Oceans 82 Conference, pp. 147154.

Jensen, F. B. (1984). "Numerical models in underwater acoustics", in $H y$ brid Formulation of Wave Propagation and Scattering (Martinus Nijhoff, Dordrecht), pp. 295-335.

Koelsch, J. (1997). "The seasonal occurrence and ecology of Florida manatees (Trichechus manatus latirostris) in coastal waters near Sarasota, FL,'
M.S. thesis, University of Southern Florida, Tampa, 121 pp.

Koelsch, J. (2001). "Reproduction in female manatees observed in Sarasota Bay, Florida," Marine Mammal Sci. 17(2), 331-342.

Kopp, B. S. (1998). "The effect of nitrate fertilization and shading on physiological and mechanical properties of eelgrass (Zostera marina)," Ph.D. dissertation, University of Rhode Island, Narragansett.

Lefebvre, L. W., Ackerman, B. A., Portier, K. M., and Pollock, K. H. (1995). "Aerial survey as a technique for estimating manatee population size and trend - problems and prospects," in Population Biology of the Florida Manatee (Trichechus manatus latirostris). National Biological Service, Information and Technical Report No. 1, pp. 63-74.

Miksis-Olds, J. L. (2006). "Manatee response to environmental noise," $\mathrm{Ph} . D$. dissertation, University of Rhode Island, Narragansett., 248 pp.

Nowacek, D. P., Buckstaff, K. C., Johnson, M. P., and Wells, R. S. (2001). Transmission loss of vessel noise in manatee environments, Report No. 721, Mote Marine Laboratory, Sarasota, FL.

Nowacek, D. P., Casper, B. M., Wells, R. S., Nowacek, S. M., and Mann, D. A. (2003). "Intraspecific and geographic variation of West Indian manatee (Trichechus manatus spp.) vocalizations (L)," J. Acoust. Soc. Am. 114(1), 66-69.

Officer, C. B. (1958). Introduction to the Theory of Sound Transmission (McGraw-Hill, New York)

Orchard, B. J., Siegmann, W. L., and Jacobson, M. J. (1992). "Threedimensional time-domain paraxial approximations for ocean acoustic wave propagation," J. Acoust. Soc. Am. 91, 788-801.

Reynolds, J. E., III (1995). "Florida manatee population biology: Research progress, infrastructure, and applications for conservation and management," in Population Biology of the Florida Manatee (Trichechus manatus latirostris), National Biological Service, Information and Technical Report No. 1. pp. 6-12.

Richardson, W., Greene, C., Malme, C., and Thomson, D. (1995). Marine Mammals and Noise (Academic, San Diego).

Sabol, B., McCarthy, E., and Rocha, K. (1997). "Hydroacoustic basis for detection and characterization of eelgrass (Zostera marina)," Proceedings of the Fourth International Conference Remote Sensing for Marine and Coastal Environments, 17-19 March, Vol. 1, pp. 679-693.

Sabol, B., Melton, R. E., Chamberlain, R., Doering, P., and Haunert, K. (2002). "Evaluation of a digital echo sounder system for detection of submersed aquatic vegetation," Estuaries 25(1), 133-141.

Sabol, B. (private communication).

Smith, K. B. (2001). "Convergence, stability, and variability of shallow water acoustic predictions using a split-step Fourier parabolic equation model," J. Comput. Acoust. 9, 243-285.

Smith, K. B., and Tappert, F. D. (1993). "UMPE: The University of Miami Parabolic Equation Model, Version 1.3," Marine Physical Laboratory, SIO, Technical Memorandum No. 432, February 1993.

Tomasko, D. A., and Dawes, C. J. (1989). "Evidence for physiological integration between shaded and unshaded short shoots of Thalassia testudinum," Mar. Ecol.: Prog. Ser. 54, 299-305.

Tomasko, D. A., Dawes, C. J., and Hall, M. O. (1996). "The effects of anthropogenic nutrient enrichment on turtle grass (Thalassia testudinum) in Sarasota Bay," Estuaries 19, 448-456.

Urick, R. J. (1983). Principles of Underwater Sound (Peninsula, Los Altos, CA). 